\title{
PROPAGANDA E PALAVRÕES ${ }^{1}$
}

\section{O outdoor "A inveja é uma merda" é um exemplo do desgaste provocado pelo abuso de vulgaridade}

Passei outro dia por um outdoor onde, sob um belo rosto de mulher, estava escrito: "A inveja é uma merda". Nem me preocupei em saber que produto o slogan malcheiroso anunciava. Bastou-me a alegria de ver finalmente escrito, em cinco letras garrafais, o nome daquilo que é tudo quanto, com a sapiência dos seus departamentos de criação e com as verbas milionárias dos seus anunciantes, a publicidade costuma nos oferecer, ou melhor dizendo, nos impingir. Com as raras e honrosas exceções de praxe, tanto mais honrosas quanto cada vez mais raras.

É de justiça reconhecer que essa palavra a que o general Cambronne ficou devendo o seu quinhão de imortalidade é hoje usada com o maior desembaraço pelo comum das pessoas, mulheres inclusive, tanto no círculo familiar quanto social. Daí que, ao transpô-la garrafalmente para um anúncio, a publicidade estaria apenas sancionando um uso genérico. Mas mesmo nisto de escolher no comportamento habitual das pessoas o que ele possa ter de mais vulgar, a propaganda mostra bem a que vem. Em tempos menos permissivos e menos desbocados que os nossos, palavras que tais costumavam ser reservadas para ocasiões especiais. Ou seja, para aqueles momentos de raiva ou de admiração extremada em que as expressões ditas de bom-tom não conseguiam exprimir satisfatoriamente a intensidade de nossos sentimentos. O palavrão ou nome feio - se preferirem uma designação mais técnica, "disfemismo", em contraposição a "eufemismo" - pertence, ou pertencia outrora, à esfera do socialmente proibido. A ele opunham o bom gosto e senso das conveniências um interdito ou proibição de uso. Empregá-lo era violar uma espécie de tabu, e precisamente disso é que lhe vinha o poder de ênfase.

\section{DESGASTE}

Largamente cultivado hoje em dia, sobretudo pelos jovens, como uma espécie de emblema da desconcentração e de anticaretice, o palavrão tende, pelo uso indiscriminado, a perder sua força enfática.

Tal como aconteceu com os superlativos, que o abuso publicitário acabou por ir progressivamente enfraquecendo - desgastada a expressividade de "grande", passou-se a "super", cujo esgotamento levou, por sua vez, a "híper".

\section{O AUTOR \\ José Paulo Paes \\ Ensaísta, poeta, tradutor e autor, entre outros, de "Um por Todos" e "A Poesia Morreu Mas Eu Juro que Não Fui Eu”.}


Um exemplo literariamente ilustre de moderação e de eficácia disfêmica, se me permitem o adjetivo pernóstico, é dado em "Angústia", de Graciliano Ramos, que não precisou de palavrões para criar a atmosfera de erotismo doentio em que se movem os seus personagens. Daí que quando aparece a certa altura do romance a exclamação "Puta!", ela ganhe uma intensidade dramática fora do comum.

Por falar em erotismo, a maneira por que ele é atualmente explorado pela mídia - onde a nudez virou arroz de festa e as cenas de sexo no cinema e na televisão já mal despertam a atenção do espectador —, só tende a prejudicar-lhe a eficácia. Isso porque a repetividade mecânica dos mesmos estímulos acaba por embotar a percepção, ao automatizá-la. George Bataille sublinha ser o interdito ou proibição que, com espicaçar o desejo, funda o erotismo. Ao tabu da nudez é que o desnudamento parcial do corpo, banalizado no striptease, deve o seu atrativo: melhor que ninguém sabem disso os fabricantes de lingerie feminina.

No mesmo jogo manhoso do interdito e da violação, de que o palavrão retira a sua força de ênfase e o erotismo a eficácia dos seus estímulos, tem a própria criação artística o motor da sua dinâmica de inovação.

Certa feita, um poeta de vanguarda disse a Júlio Cortázar que àquela altura da vida só lhe interessava fazer o que não pudesse ser feito. Ao que respondeu o romancista: "Muito bem, mas não se esque- ça de que aquilo que não se pode fazer é sempre definido e delimitado pelo que se pode fazer".

No século passado, Nietszche declarou que Deus estava morto, que tudo era doravante permitido. E quando, no nosso século, mais precisamente em 1968, os estudantes de Paris se insurgiram contra a ordem burguesa respaldada por seus pais e rabiscaram nos muros a célebre divisa do "É proibido proibir", estavam retocando sem saber, com as tintas do libertarismo, a mesma velha cara da intolerância. Ao coibir qualquer manifestação que não se enquadre estritamente na sua ortodoxia, a intolerância busca anular a diferença e barrar a emergência do novo. Ao aceitar passivamente tudo quanto surja, a permissividade embota a percepção da diferença e deixa que o novo se perca na anodinia geral.

Revidar uma negação com outra negação é fazer o jogo dela: a estrada real da liberdade não passa por aí. Passa antes pela afirmatividade da tolerância, que se empenha a cada passo em reconhecer a diferença e compreender-lhe as razões. Mesmo que não seja para adotá-las, para reconhecerlhes direito de cidadania. Comparando agora alhos com bugalhos, só para fins de ilustração: graças a sua lucidez crítica, que não abdica do direito de analisar e escolher, pode o espírito de tolerância distinguir as razões de ser de uma obra de choque como "O Império dos Sentidos", para citar um exemplo "clássico" - da morna vulgaridade, que inculca por chocante, de estratagemas publicitários como o que nos serviu aqui de ponto de partida. 